\title{
Első lépés egy egységes szemlélet felé: az Alkohol Megvonási Skála bevezetése a hazai betegellátási gyakorlatba
}

\author{
Lázár Bence András dr. ${ }^{1}$ - Pribék Ildikó Katalin ${ }^{1}$ \\ Kovács Csenge dr. ${ }^{1}$ - Demeter Ildikó dr. ${ }^{2}$ - Kálmán János dr. ${ }^{2}$ \\ Szemelyácz János dr. ${ }^{3}$ - Kelemen Gábor dr. ${ }^{4}$ - Janka Zoltán dr. ${ }^{2}$ \\ Demetrovics Zsolt dr. ${ }^{5}$ - Andó Bálint dr. ${ }^{1}$ \\ 'Szegedi Tudományegyetem, Általános Orvostudományi Kar, Pszichiátriai Klinika, \\ Addiktológiai Munkacsoport, Szeged \\ ${ }^{2}$ Szegedi Tudományegyetem, Általános Orvostudományi Kar, Pszichiátriai Klinika, Szeged \\ ${ }^{3}$ Baranya Megyei Önkormányzat Közegészségügyi, \\ Narkomán Fiatalokat Gyógyító-Foglalkoztató Közalapítványa (INDIT Közalapítvány), Pécs \\ ${ }^{4}$ Pécsi Tudományegyetem, Bölcsészettudományi Kar, Társadalmi Kapcsolatok Intézete, Pécs \\ ${ }^{5}$ Eötvös Loránd Tudományegyetem, Pedagógiai és Pszichológiai Kar, Pszichológiai Intézet, Budapest
}

Bevezetés és célkitüzés: Alkoholbetegek egészségügyi ellátása során az alkoholfogyasztás csökkentésével vagy annak elhagyásával alkohol okozta megvonási szindróma alakulhat ki. Jelenleg hazánkban nem áll rendelkezésre olyan standardizált mérőeszköz, amellyel az alkoholmegvonás tünetei mérhetők lennének. A nemzetközi szakirodalom, illetve irányelvek a megvonás tüneteinek monitorozására elsődlegesen a Clinical Institute Withdrawal Assessment of Alcohol, Revised mérőeszközt ajánlják, melynek hazai bevezetése hiánypótlónak tekinthető. A jelen vizsgálat célja a Clinical Institute Withdrawal Assessment of Alcohol, Revised hazai változata (Alkohol Megvonási Skála) pszichometriai mutatóinak feltárása, illetve a méróeszköz alkalmazásának bemutatása.

Módszer: A vizsgálat a Szegedi Tudományegyetem Pszichiátriai Klinikájára alkohol okozta megvonási szindróma iránydiagnózissal osztályra felvett páciensek $(\mathrm{n}=30)$ körében történt, utánkövetéses elrendezésben. Kétnaponta, hat alkalommal került felvételre az Alkohol Megvonási Skála, illetve mellette a Klinikai Globális Összbenyomás - Súlyosság Skála. A felvételek során kapott átlagok összehasonlítása ismételt méréses varianciaanalízissel történt. Belső konzisztenciai mutatók (Cronbach-alfa, tétel-totál korreláció), konvergens és divergens validitási mutatók (Alkohol Megvonási Skála, illetve a Klinikai Globális Összbenyomás - Súlyosság Skála közötti Pearson korrelációs elemzés alapján) kerültek kiszámításra.

Eredmények: Szignifikáns csökkenés volt megfigyelhető a 6 adatfelvételi időpontban az Alkohol Megvonási Skála $(\mathrm{F}=$ 202,46, p<0,001), illetve a Klinikai Globális Összbenyomás - Súlyosság Skála $(F=503,04, p<0,001)$ pontszámainak esetében. A Cronbach-alfa-értékek az első 3 mérési napon 0,7 felett voltak. Az egy időben felvett Alkohol Megvonási Skála és a Klinikai Globális Összbenyomás - Súlyosság Skála minden esetben 0,45 feletti korrelációt mutatott. Következtetés: Az Alkohol Megvonási Skála megbízható és érvényes mérőeszköz a megvonási tünetek részletes szimptomatológiai vizsgálatára. Így lehetővé teszi a hazai betegellátási gyakorlatban az alkoholmegvonás tüneteinek felismerését és súlyosságának meghatározását.

Orv Hetil. 2019; 160(30): 1184-1192.

Kulcsszavak: alkohol, megvonási szindróma, pszichometria, Alkohol Megvonási Skála

The first step towards a unified approach: validation of the Hungarian version of the Clinical Institute Withdrawal Assessment of Alcohol, Revised in Hungarian general hospital settings

Introduction and aim: The available literature and protocols have unequivocally suggested that the Clinical Institute Withdrawal Assessment of Alcohol, Revised is a psychometric scale for identifying and following the signs of alcohol withdrawal. However, there has not been any validated tool for the identification of withdrawal symptoms in Hun- 
garian general hospital settings. The aim of the present study was to evaluate the validity and the reliability of the Hungarian version of this scale among patients hospitalized with alcohol withdrawal syndrome.

Method: The translation of the scale into Hungarian was done by 'back translation' method, followed by testing the face validity. The empirical phase was performed in the Department of Psychiatry, University of Szeged. Patients admitted with alcohol withdrawal syndrome $(\mathrm{n}=30)$ were recruited from the inpatient units of the clinic. Clinical Institute Withdrawal Assessment of Alcohol, Revised and Clinical Global Impression - Severity Scale were recorded every two days. Statistical comparisons of data were performed with repeated-measures ANOVA. Cronbach's alpha, item-total correlation, convergent and discriminant validity were determined.

Results: Significant decrease of the total scores of Clinical Institute Withdrawal Assessment of Alcohol, Revised and Clinical Global Impression - Severity Scale was observed between the six measurements $(\mathrm{F}=202.46, \mathrm{p}<0.001 ; \mathrm{F}=$ $503.04, \mathrm{p}<0.001)$. Cronbach alpha values were above 0.7 during the first 3 measurement days. The withdrawal and severity scores recorded the same day showed positively significant correlations $(>0.45)$.

Conclusion: Our findings demonstrate that the Clinical Institute Withdrawal Assessment of Alcohol, Revised is a reliable and valid psychometric tool for the detailed analysis of withdrawal symptoms in Hungarian general hospital settings.

Keywords: alcohol withdrawal syndrome, psychometry, Clinical Institute Withdrawal Assessment of Alcohol, Revised

Lázár BA, Pribék IK, Kovács Cs, Demeter I, Kálmán J, Szemelyácz J, Kelemen G, Janka Z, Demetrovics Zs, Andó B. [The first step towards a unified approach: validation of the Hungarian version of the Clinical Institute Withdrawal Assessment of Alcohol, Revised in Hungarian general hospital settings]. Orv Hetil. 2019; 160(30): 11841192.

(Beérkezett: 2019. január 27.; elfogadva: 2019. március 14.)

\section{Rövidítések}

AMS = Alkohol Megvonási Skála; AMSZ = alkohol okozta megvonási szindróma; AUDIT = Alkoholhasználat Zavarainak Szürőtesztje; CGI-S = (Clinical Global Impression - Severity Scale) Klinikai Globális Összbenyomás - Súlyosság Skála; CIWA-A = Clinical Institute Withdrawal Assessment of Alcohol; CIWA-Ar $=($ Clinical Institute Withdrawal Assessment of Alcohol, Revised) Alkohol Megvonási Skála; SD = standard deviáció; SZTE = Szegedi Tudományegyetem

Az alkoholfogyasztás világszerte az egyik legsúlyosabb egészségkárosító magatartás a felnőtt lakosság körében. Az Egészségügyi Világszervezet 2016-os adatai alapján megállapítható, hogy az évi egy före jutó alkoholfogyasztás Európában 9,8 liter [1], míg hazánkban ez az érték 11,4 liter tiszta alkohol. Hazánk az 51 vizsgált európai országból a 16. helyet foglalja el [2], jelezve, hogy Magyarországon az alkoholhasználat a legjelentősebb népegészségügyi problémák közé tartozik a morbiditási és mortalitási adatok alapján.

Az alkoholhasználat zavarával diagnosztizált páciensek felénél az alkoholfogyasztás csökkentésével vagy annak felhagyásával alkohol okozta megvonási szindróma (AMSZ) alakul ki [3]. A megvonás első tünete a tremor, amely 6-8 órán belül jelentkezik, majd ezt 8-12 órán belül a globális kognitív zavar követi, végül 12-24 órán belül kiteljesedik a megvonási szindróma [4]. Az AMSZ talaján súlyosabb esetben delírium is megjelenhet [5]. Az AMSZ az egészségügyi ellátórendszer minden szegmensében beavatkozást igénylő kórállapotnak tekinthető. A hazai klinikai gyakorlatban a megvonási tünetcso- port felismerése, nyomon követése és gyógyszeres kezelése elsősorban a megfigyelt pszichés állapot, a neurológiai és belgyógyászati fizikális vizsgálat, továbbá a vitális paraméterek rögzítése mentén történik, döntően osztályos keretek között.

Az elmúlt évtizedekben számos, az AMSZ tüneteinek objektivizálására alkalmas mérőeszközt fejlesztettek ki: Alcohol Withdrawal Symptom Checklist, Anxiety Sweats Tremor Scale, Glasgow Modified Alcohol Withdrawal Scale, Brief Alcohol Withdrawal Scale [6-8]. Ezek közül a nemzetközi gyakorlatban a Clinical Institute Withdrawal Assessment of Alcohol (CIWA-A) skála hatékonysága bizonyult kiemelkedőnek $[9,10]$. A CIWA-A eredetileg 15 tételt tartalmazott, melyeket a késóbbiekben a magasabb konzisztencia elérése érdekében 10 tételre redukáltak: Clinical Institute Withdrawal Assessment of Alcohol, Revised (CIWA-Ar); ennek klinikai gyakorlatban történő használata nagyfokú hatékonyságot mutatott [ 9 , 11]. Így a rövidebb, 10 tételes mérőeszköz a hányinger és hányás (1), a tremor (2), a verejtékezés (3), a taktilis, auditoros és vizuális zavarok (4-6), a szorongás (7), az agitáció (8), a fejfájás és feji nyomásérzékenység (9), illetve az orientáció, a tudat integritása (10) tételeket tartalmazza [9]. A skála előnye a rövid adminisztrációs idő, mivel felvétele csupán 2-5 percet vesz igénybe [12]. A rendszeres tesztfelvétel segít a kezelésre adott válasz mértékének meghatározásában, valamint jelzi, ha szükséges további gyógyszeres beavatkozás [9]. Számos korábbi szakirodalom alátámasztotta a CIWA-Ar megbízhatóságát, illetve érvényességét. Sullivan és mtsai (1989) eredményei alapján megállapítható, hogy a rövidített skála megfelelő prediktív erôvel bír az eredeti skála össz- 
pontszámára, illetve a tétel-totál korrelációk is megfelelőnek bizonyultak [9]. A CIWA-Ar pszichometriai mutatói a különböző kultúrákban, illetve mintákon nagymértékű eltérést mutatnak $[6,13]$. A skálát több nyelvre lefordították, német, illetve kínai mintán optimális megbízhatósági értékeket találtak [14, 15].

Összefoglalva elmondható, hogy az AMSZ tüneteinek monitorozására az 1989-ben kifejlesztett skála az egyik legalkalmasabb méróeszköz [6,9-11, 13-15]. A CIWAAr-t mind a National Institute for Health and Care Excellence, mind a National Institutes of Health ajánlja protokolljaiban. A nemzetközi gyakorlat, illetve protokollok alapján a CIWA-Ar a hazai alkoholbetegek ellátásában is használható lehet a megvonásos tünetek felismerésére és nyomon követésére. A CIWA-Ar nem csupán az AMSZ súlyosságának meghatározására, hanem számos gyógyszer- és klinikai vizsgálatban is alkalmazható [1622].

Hazánkban jelenleg nem áll rendelkezésünkre olyan standardizált mérőeszköz, amellyel az alkoholmegvonási tünetek objektivizálhatók lennének, továbbá a CIWA-Ar betegellátási gyakorlatba történő bevezetésére, szisztematikus vizsgálatára még nem került sor. Így a jelen vizsgálat alapvető célját a CIWA-Ar pszichometriai mutatóinak feltárása képezte, a mérőeszköz megbízhatósági és érvényességi mutatóin keresztül.

\section{Módszer}

\section{Az Alkohol Megvonási Skála bemutatása, forditási folyamata, látszatérvényessége}

A CIWA-Ar az AMSZ tüneteinek felmérésére, monitorozására, gyógyszeres kezelésének követésére alkalmas kiegészítő mérőeszköz [9]. A CIWA-Ar tíz tételének pontozása a felvételét végző személy megfigyelésein, illetve a páciens válaszain alapszik. A vizsgálatvezető minden tételt egy 0-tól 7-ig terjedő skálán értékel, a mérőeszközön maximálisan 67 pont adható [9]. A magasabb pontszám súlyosabb megvonási tüneteket jelez. Alkoholhasználati zavarban a skála felvétele hozzájárul az AMSZ diagnózisának megerősítéséhez, monitorozásához, továbbá az optimális terápia megválasztásához. A mérőeszköz hazai verziójának fordítása „visszafordításos” módszerrel történt, melynek során angolról magyar nyelvre történt a fordítása, majd vissza [23]. A fordításokat követően kialakult verziót - Alkohol Megvonási Skála (AMS) - egy szakértői csoport a látszatérvényesség tekintetében megvizsgálta (D. Zs., K. G., Sz. J.); a mérőeszköz tételeire vonatkozóan a csoporton belül konszenzus született. A szakértői csoport által jóváhagyott mérőeszköznek az empirikus vizsgálata történt meg a jelen vizsgálat keretében (1. melléklet) [9]. A tételek sorszámmal sem az eredeti, sem az általunk lefordított és alkalmazott magyar nyelvú verzióban nem lettek ellátva, ugyanakkor az eredmények elemzésekor a könnyebb áttekinthetőség kedvéért a következő módon hivatkozunk a tételekre: 1) hányinger és hányás, 2 ) tremor, 3 ) verejtékezés, 4) taktilis zavarok, 5 ) auditoros zavarok 6) vizuális zavarok, 7) szorongás, 8) agitáció, 9) fejfájás és feji nyomásérzékenység, 10) orientáció, a tudat integritása.

\section{A résztvevők és a vizsgálat menete}

Vizsgálatunkba a Szegedi Tudományegyetem SzentGyörgyi Albert Klinikai Központja Pszichiátriai Klinikájának fekvőbeteg-ellátó egységein alkohol okozta megvonási szindróma (F1030) iránydiagnózissal felvett páciensek (életkor: 18 és 65 év között) kerültek bevonásra. Informált beleegyezést követően, a vizsgálatban önként részt vevő minden beteggel összesen 6 alkalommal, 2 naponta, 10 nap alatt került felvételre egy tesztcsomag. Az alkoholfogyasztási szokások, a megvonási tünetek feltárása a klinikai betegellátás részét képezték. Jelen vizsgálatunk során az interjúk és a megfigyelések alapján, strukturáltan történt ezen adatok rögzítése a tesztcsomag felvételén keresztül. A mérőeszközök utánkövetéses felvétele a használatukban jártas orvos által történt a vizsgálatba történő bevonást követően. A jelen eredmények egy nagyobb vizsgálat részét képezik. A vizsgálatot a Szegedi Tudományegyetem Szent-Györgyi Albert Klinikai Központjának Regionális Humán Orvosbiológiai Kutatásetikai Bizottsága szakmai-etikai szempontból jóváhagyta $(28 / 2018$, SZTE).

\section{Méröeszközök, háttérváltozók}

A vizsgálati személyekkel az első alkalommal egy általános demográfiai kérdéssor került felvételre, továbbá az Alkoholhasználat Zavarainak Szürőtesztje (AUDIT) interjú formájában. Az AUDIT az alkoholhasználat zava-

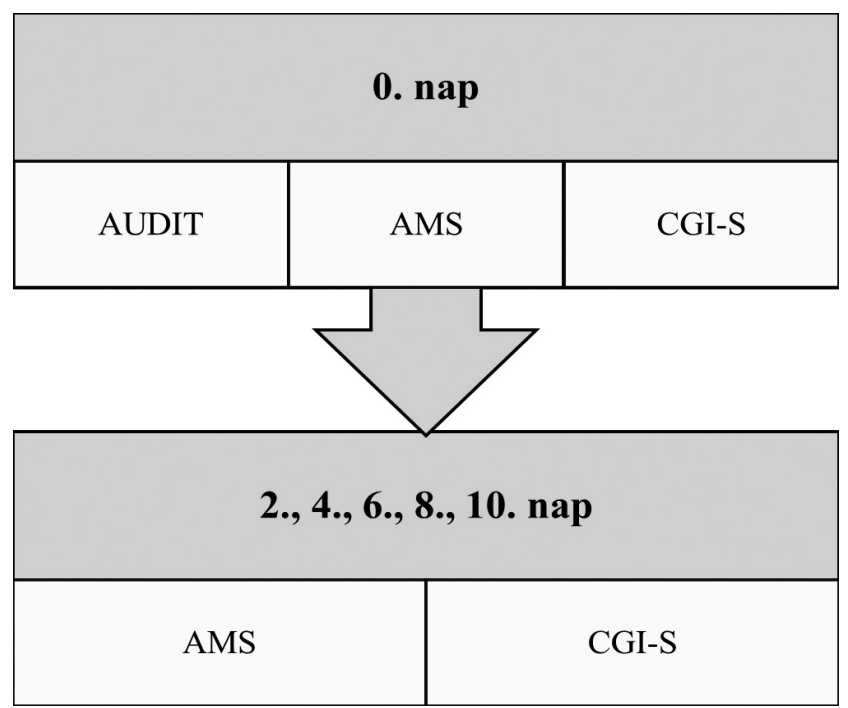

1. ábra $\quad$ Az Alkohol Megvonási Skála validálási vizsgálatának menete AUDIT $=$ Alkoholhasználat Zavarainak Szűrőtesztje; AMS = Alkohol Megvonási Skála; CGI-S = Klinikai Globális Összbenyomás - Súlyosság Skála 
1. táblázat Az Alkohol Megvonási Skála és a Klinikai Globális Összbenyomás - Súlyosság Skála átlagpontszámainak változása

\begin{tabular}{lcccccc}
\hline AMS & AMS 1 & AMS 2 & AMS 3 & AMS 4 & AMS 5 & AMS 6 \\
\hline $\begin{array}{l}\text { Átlag } \\
\text { (szórás })\end{array}$ & $\begin{array}{c}20,93 \\
(7,45)\end{array}$ & $\begin{array}{c}11,53 \\
(4,95)\end{array}$ & $\begin{array}{c}5,5 \\
(3,46)\end{array}$ & $\begin{array}{c}2,93 \\
(2,44)\end{array}$ & $\begin{array}{c}1,43 \\
(2,07)\end{array}$ & $\begin{array}{c}0,43 \\
(0,82)\end{array}$ \\
\hline CGI-S & CGI-S 1 & CGI-S 2 & CGI-S 3 & CGI-S 4 & CGI-S 5 & CGI-S 6 \\
\hline Átlag & 4,33 & 3,27 & 2,47 & 1,77 & 1,23 & 1,06 \\
(szórás) & $(1,12)$ & $(1,08)$ & $(0,86)$ & $(0,63)$ & $(0,57)$ & $(0,36)$ \\
\hline
\end{tabular}

AMS = Alkohol Megvonási Skála; CGI-S = Klinikai Globális Összbe nyomás - Súlyosság Skála

\begin{tabular}{l|l} 
2. táblázat & $\begin{array}{l}\text { Az Alkohol Megvonási Skála Cronbach-alfa-értékei a } 6 \text { felvétel } \\
\text { során }\end{array}$
\end{tabular} A felvétel AMS 1 AMS 2 AMS 3 AMS 4 AMS 5 AMS 6 alkalma

\begin{tabular}{lllllll}
\hline Cronbach- $\alpha$ & 0,732 & 0,745 & 0,704 & 0,589 & 0,478 & 0,647
\end{tabular}

AMS = Alkohol Megvonási Skála

rának súlyosságát mérte [24]. A további 5 vizsgálati időpont során a Klinikai Globális Összbenyomás - Súlyosság Skála (Clinical Global Impression - Severity Scale [CGI$\mathrm{S}]$ ) mentén a klinikus általános súlyosságbecslést adott 0-tól 7-ig a páciens állapotára vonatkozóan (1. ábra). A magasabb pontszám súlyosabb állapotot tükrözött [25]. Emellett minden alkalommal felvételre került az AMS.

\section{Statisztikai elemzések}

A minta leíró statisztikai elemzésein túl a pszichometriai elemzések keretében reliabilitási és validitási vizsgálatokat végeztünk.

A reliabilitási, belső konzisztenciai mutatók közül az AMS-ra vonatkozóan mind a 6 felvétel esetében Cronbach-alfa-értéket számoltunk. Az első 3 alkalommal történt AMS-felvétel esetében részletesebb reliabilitási elemzést végeztünk: a Cronbach-alfa mutatón kívül tétel-totál korrelációt, illetve Cronbach-alfa-értéket számoltunk a tétel törlése esetében.

A további validitási vizsgálatok a konvergens validitás ellenőrzésére terjedtek ki, melyek során Pearson-féle korrelációs számításokat végeztünk a CGI-S és az AMS pontszámai között.

Az AMSZ lezajlása a szakirodalom alapján hozzávetőlegesen 7 nap alatt történik [26]. Az AMS ökológiai validitási tesztelése utánkövetéses módszerrel történt, 10 nap alatt hatszor került felvételre, így az összpontszám 6 mérés során kapott átlagait ismételt méréses varianciaanalízis módszerével végeztük el, Bonferroni-utóteszt alkalmazásával. Így vált vizsgálhatóvá az a szakirodalomban ismert jelenség, hogy a megvonási tünetek csökkenő tendenciát mutatnak, és 7-10 napon belül megszűnnek.

\section{Eredmények}

A bevont páciensek $(\mathrm{n}=30) 20 \%$-a nö $(\mathrm{n}=6)$; átlagéletkoruk 45,7 év $(S D=9,5)$. Az AUDIT-átlagpontszámuk 30,7 ( $\mathrm{SD}=5,8)$, ami súlyos alkoholhasználati zavart tükröz. A 6 alkalom során kapott AMS- és CGI-S-átlagpontszámok az 1. táblázatban láthatók.

A 6 alkalommal felvett AMS Cronbach-alfa megbízhatósági vizsgálatok eredményei a 2. táblázatban láthatók. A csökkenő értékek arra utalnak, hogy a mérőeszköz megbízhatóbb a megvonási szindróma lezajlásának első szakaszában (AMS 1-AMS 3), mint a második felében.

Az első 3 alkalommal felvett AMS esetében tétel-totál korrelációt, illetve Cronbach-alfa mutatót számoltunk az egyes tételek törlése esetében. Ezen eredmények a 3. táblázatban láthatók. A 6. tétel bizonyul a legkevésbé megbízhatónak, míg a 2., 5., 10. tétel 0,2-0,3 közötti értéket mutat az első mérés esetében. A 6. tétel tünik a leggyengébbnek az 5 . és a 10 . tétel mellett.

A konvergens validitás eredményeit a 4. táblázat tartalmazza. Látható az AMS- és a CGI-S-korrelációk min-

3. táblázat |Az Alkohol Megvonási Skála tétel-totál korreláció értékei és a tétel-törlés utáni Cronbach-alfa-értékek

\begin{tabular}{|c|c|c|c|c|c|c|c|c|}
\hline 1. & $\begin{array}{l}\text { Tétel-totál } \\
\text { korreláció }\end{array}$ & $\begin{array}{c}\text { Alfa a tétel } \\
\text { nélkül }\end{array}$ & 2. & $\begin{array}{l}\text { Tétel-totál } \\
\text { korreláció }\end{array}$ & $\begin{array}{l}\text { Alfa a tétel } \\
\text { nélkül }\end{array}$ & 3. & $\begin{array}{l}\text { Tétel-totál } \\
\text { korreláció }\end{array}$ & $\begin{array}{c}\text { Alfa a tétel } \\
\text { nélkül }\end{array}$ \\
\hline AMS1.1 & 0,483 & 0,699 & AMS2.1 & 0,640 & 0,691 & AMS3.1 & 0,321 & 0,690 \\
\hline AMS1.2 & 0,251 & 0,740 & AMS2.2 & 0,512 & 0,711 & AMS3.2 & 0,550 & 0,659 \\
\hline AMS1.3 & 0,532 & 0,686 & AMS2.3 & 0,756 & 0,655 & AMS3.3 & 0,738 & 0,597 \\
\hline AMS1.4 & 0,437 & 0,706 & AMS2.4 & 0,572 & 0,703 & AMS3.4 & 0,516 & 0,660 \\
\hline AMS1.5 & 0,286 & 0,728 & AMS2.5 & 0,040 & 0,757 & AMS3.5 & 0,071 & 0,714 \\
\hline AMS1.6 & $-0,029$ & 0,749 & AMS2.6 & $-0,065$ & 0,760 & AMS3.6 & 0,000 & 0,713 \\
\hline AMS1.7 & 0,793 & 0,644 & AMS2.7 & 0,523 & 0,705 & AMS3.7 & 0,502 & 0,655 \\
\hline AMS1.8 & 0,601 & 0,670 & AMS2.8 & 0,377 & 0,737 & AMS3.8 & 0,430 & 0,670 \\
\hline AMS1.9 & 0,339 & 0,719 & AMS2.9 & 0,353 & 0,734 & AMS3.9 & 0,277 & 0,698 \\
\hline AMS1.10 & 0,259 & 0,736 & AMS2.10 & 0,168 & 0,751 & AMS3.10 & 0,000 & 0,713 \\
\hline
\end{tabular}

AMS = Alkohol Megvonási Skála 
Az Alkohol Megvonási Skála és a Klinikai Globális Összbenyomás - Súlyosság Skála méróeszközök konvergens validitási mutatói

\begin{tabular}{lcccccc}
\hline & CGI-S 1 & CGI-S 2 & CGI-S 3 & CGI-S 4 & CGI-S 5 & CGI-S 6 \\
\hline AMS 1 & $0,702^{* *}$ & $0,375^{*}$ & $0,483^{* *}$ & 0,226 & $-0,078$ & $-0,188$ \\
AMS 2 & $0,530^{* *}$ & $0,475^{* *}$ & $0,546^{* *}$ & 0,342 & 0,236 & 0,075 \\
AMS 3 & $0,434^{*}$ & $0,461^{*}$ & $0,637^{*}$ & $0,517^{*}$ & $0,464^{* *}$ & 0,136 \\
AMS 4 & 0,309 & $0,646^{* *}$ & $0,637^{*}$ & $0,507^{*}$ & $0,755^{* *}$ & 0,314 \\
AMS 5 & 0,261 & $0,607^{*}$ & $0,654^{* *}$ & $0,425^{*}$ & $0,758^{* *}$ & 0,324 \\
AMS 6 & $-0,013$ & 0,021 & 0,095 & 0,070 & 0,295 & $0,478^{* *}$
\end{tabular}

${ }^{* *} \mathrm{p}<0,001 ;{ }^{*} \mathrm{p}<0,01$

AMS = Alkohol Megvonási Skála; CGI-S = Klinikai Globális Összbenyomás Súlyosság Skála

tázataiból, hogy az egy időtartamon belül felvett tesztek szignifikáns összefüggést jeleztek. Továbbá az egy időben felvett AMS- és CGI-S-értékek minden esetben 0,45 feletti korrelációt mutatnak.

A 2. és 3. ábrán látható ismételt méréses varianciaanalízis azt mutatja, hogy szignifikáns csökkenés figyelhető meg a 6 adatfelvételi időpontban az AMS ( $\mathrm{F}=202,46$, $\mathrm{p}<0,001)$, illetve a CGI-S $(\mathrm{F}=503,04, \mathrm{p}<0,001)$ pontszámai esetében. A Bonferroni-utóteszt alapján az 5 . és 6. mérési nap között már nincs szignifikáns különbség, sem az AMS ( $\mathrm{p}=0,175)$, sem pedig a CGI-S összpontszámai esetében $(\mathrm{p}=0,097)$.

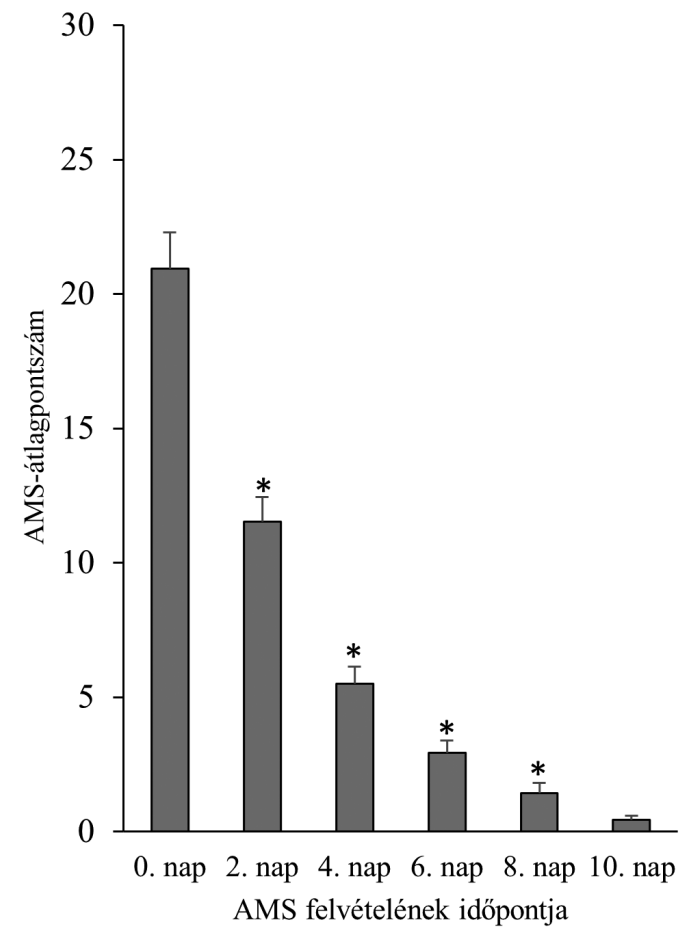

2. ábra

$$
\mid \begin{aligned}
& \text { Az Alkohol Megvonási Skála átlagpontszámainak változása } \\
& { }^{*} \mathrm{p}<0,05 \\
& \text { AMS = Alkohol Megvonási Skála }
\end{aligned}
$$

\section{Megbeszélés}

Vizsgálatunkban az AMS validálását végeztük el klinikai mintán. A fordítás eredményeképpen kialakított mérőeszköz látszatérvényessége, továbbá a korábbi szakirodalmi adatokkal [6, 9, 13-15] egybehangzóan a pszichometriai mutatói is megfelelőnek bizonyultak.

Hazai vizsgálatunk alapján az AMS megbízhatóbb a megvonási szindróma lezajlásának kezdetében (az első 4 nap). Ugyanakkor a 6. napon (a 4. adatfelvételi napnak felel meg), illetve utána láthatók gyengébb belső konzisztenciaértékek. Az AMSZ lezajlásának elején, amikor súlyosabbak a tünetek, a méróeszköz tételei egy irányba mutatnak, biztonsággal mérik a tünetek súlyosságát, az AMSZ lezajlásának második felével összevetve. Ennek hátterében elsősorban a megvonási szindróma tüneteinek időbeli lefolyása, regressziója állhat.

A tétel-totál korrelációk felvetik a további, esetlegesen rövidebb változatok kialakítását, ami a szakirodalomban is látható példa [27], tekintettel arra, hogy bizonyos tételek kihagyása esetében (3. táblázat) növelhető a Cronbach-alfa megbízhatósági mutató. További vizsgálatokat igényel a későbbiekben a rövidebb verziók pszichometriai mutatóinak elemzése, illetve a mutatók robusztusságának teszteléséhez szükséges a minta méretének bővítése. A rövidebb változatok kialakításának előnye lehet még a klinikai alkalmazhatóság növelése azáltal, hogy a felvételi idő csökkenthető.

Az AMS érvényességét jelzi, hogy szignifikánsan együtt jár az egy alkalommal felvett AMS- és CGI-Spontszám, mely tükrözi a szakirodalmi adatokat [15].

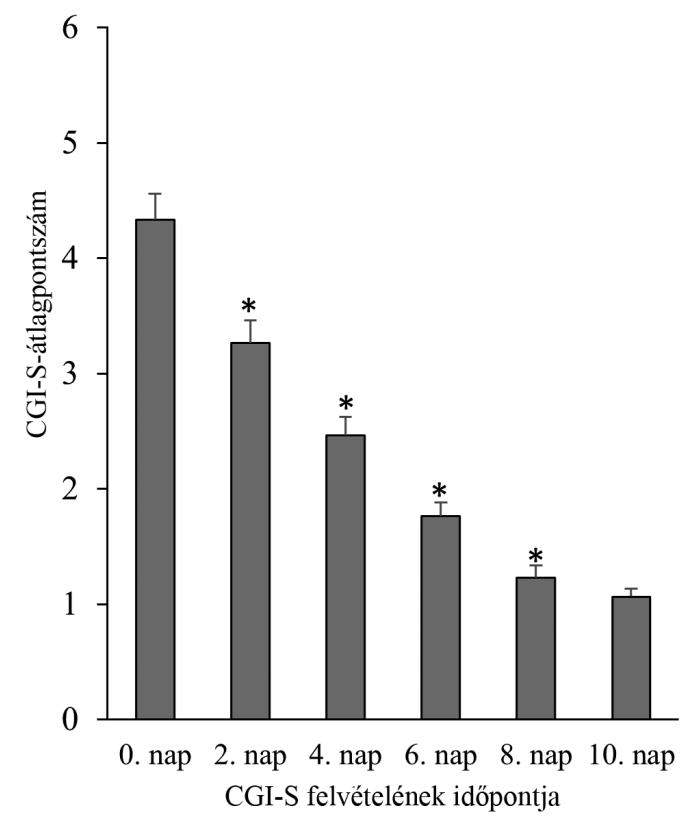

3. ábra \begin{tabular}{|l} 
A Klinikai Globális Összbenyomás - Súlyosság Skála átlagpont- \\
számainak változása \\
*p $<0,05$ \\
CGI-S = Klinikai Globális Összbenyomás - Súlyosság Skála
\end{tabular} 
A korrelációs mátrixból megállapítható továbbá (4. táblázat), hogy az 1-2. időpontban felvett AMS-pontszám kevésbé, illetve nem korrelál a 4., 5., 6. időpontban felvett CGI-S-pontszámmal. Ez a jelenség egyidejűleg hívja fel a figyelmet a mérőeszköz konvergens és divergens érvényességére. Az AMSZ lezajlása a szakirodalom alapján hozzávetőlegesen 7 nap [26]. A csökkenő átlagpontszámok alapján elmondható, hogy valószínúleg 2-3 nap után a gyógyszeres kezelés hatása megkezdődik, aminek következtében a megvonási tünetek jelentősen csökkennek, így már a 4. napon 5 körüli AMS-értéket mutatnak. A tünetek a megvonás természetes folyamata miatt is csökkennének, ám felvetődik, hogy nem ebben az ütemben. A jelen vizsgálat azt mutatja, hogy az AMSZ-pontszámok alapján a 8. és a 10. nap között már nincs szignifikáns csökkenés a megvonási tünetek intenzitásában.

Az AMS az osztályos ellátás során az egészségügyi személyzet által rendszeresen használható, mely elősegíti az AMSZ súlyosságának nyomon követését és a gyógysze- res beavatkozás megválasztását. Fontos megjegyezni, hogy az alkoholmegvonásos tünetegyüttes az egészségügyi ellátás bármely területén beavatkozást igénylő állapot lehet, így az AMS alkalmazása nem kizárólagosan pszichiátriai, addiktológiai osztályokon történhet, ugyanakkor a mérőeszköz felvételének fontos, megfontolandó indikációi és kontraindikációi vannak (2. melléklet) $[9]$.

Az AMS klinikai kutatások megfelelő szürőtesztjeként is használható, melynek segítségével kategorizálni lehet a vizsgálati személyeket az akut megvonási tünetek súlyosságának tekintetében [28-30].

\section{Következtetés}

Megállapítható, hogy az AMS megbízható és érvényes az alkoholmegvonási szindróma részletes szimptomatológiai vizsgálatára, ezért bevezetését javasoljuk az alkoholbetegek hazai ellátásának folyamatába.

1. melléklet |Alkohol Megvonási Skála (CIWA-Ar) [9]

Páciens neve:

Dátum:

Időpont:

(24 órás jelölés, éjfél $=$ 00:00)

Pulzus vagy szívfrekvencia, egy perc alatt:

Vérnyomás:

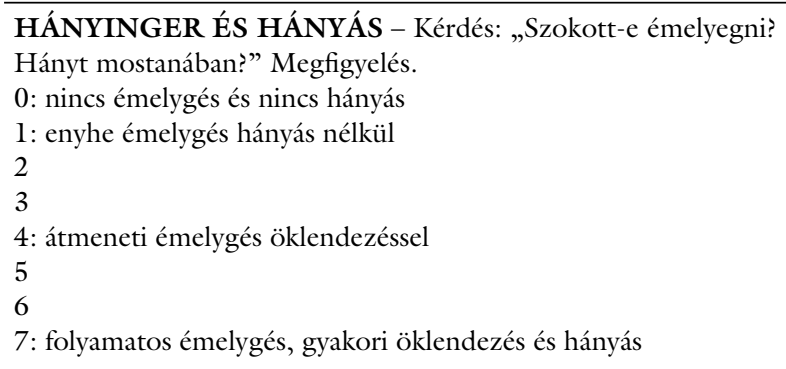

TREMOR - Kinyújtott kéz és széttartott ujjak. Megfigyelés.

0 : nincs tremor

1: nem látható tremor, de az ujjhegyek érintésével észlelhető

4: mérsékelt tremor, ha a páciens karjai nyújtva vannak

7: súlyos tremor, a karok kinyújtása és az ujjak széttartása nélkül is észlelhetó
TAKTILIS ZAVAROK - Kérdés: „Tapasztalt-e viszketést, bizsergést, égető érzést, zsibbadást vagy olyan érzést, mintha bogarak másznának a bőrén vagy a bőre alatt?” Megfigyelés.

0 : nem tapasztalt ilyet

1: nagyon enyhe viszketés, bizsergés, égető érzés vagy zsibbadás

2: enyhe viszketés, bizsergés, égető érzés vagy zsibbadás

3: mérsékelt viszketés, bizsergés, égető érzés vagy zsibbadás

4: mérsékelt hallucinációk

5: súlyos hallucinációk

6: extrém súlyos hallucinációk

7: folyamatos hallucinációk

AUDITOROS ZAVAROK - Kérdés: „Hangosabbnak hallja-e a környezó hangokat? Élesebbek-e a hangok? Megijesztik-e Önt? Hall bármi olyasmit, ami zavaró az Ön számára? Hall bármi olyat, amiről tudja, hogy nincs jelen?" Megfigyelés.

0: nem jellemzó

1: kismértékben hangosabb vagy ijesztő zajok

2: enyhén hangosabb vagy ijesztő zajok

3: mérsékelten hangosabb vagy ijesztő zajok

4: közepesen súlyos hallucinációk

5: súlyos hallucinációk

6: extrém súlyos hallucinációk

7: folyamatos hallucinációk

VIZUÁLIS ZAVAROK - Kérdés: „Túlságosan fényesnek észleli-e a fényeket? A fények színe megváltozott-e? Zavarja-e a szemét? Lát-e bármi olyat, ami zavarja Önt? Lát-e olyan dolgokat, amelyekról tudja, hogy nincsenek jelen?" Megfigyelés.

0: nem jellemző

1: nagyon enyhe érzékenység

2: enyhe érzékenység

3: mérsékelt érzékenység

4: közepesen súlyos hallucinációk

5: súlyos hallucinációk

6: extrém súlyos hallucinációk

7: folyamatos hallucinációk 


\section{1. melléklet folyt.}

SZORONGÁS - Kérdés: „Idegesnek érzi magát?” Megfigyelés.

0: nincs szorongás, nyugodt

1: enyhe szorongás

4: mérsékelt fokú szorongás, tartózkodó, szorongás tehát feltételezhető

5

7: akut, pánikszerú állapot, amely súlyos fokú delíriumhoz vagy kut szkizofreniform reakcióhoz hasonló
FEJFÁJÁS, FEJI NYOMÁSÉRZÉKENYSÉG - Kérdés: „Szokott-e fájni a feje? Szokta-e úgy érezni, mintha egy pánt szorítaná a fejét?” A szédülés és a feledékenység nem értékelendő. Egyéb tünetek esetén a súlyosságot pontozzuk.

0: nem jellemző

1: nagyon enyhe

2: enyhe

3: mérsékelt

4: közepesen súlyos

5: súlyos

6: nagyon súlyos

7: extrém súlyos

AGITÁCIÓ - Megfigyelés.

0 : normál aktivitás

ORIENTÁCIÓ ÉS A TUDAT INTEGRITÁSA - Kérdés: „Milyen nap van ma? Hol vagyunk? Ki vagyok én?”

1: a szokásosnál aktívabb

4: mérsékelt szorongás és nyugtalanság

0: orientált és következetes válaszokat ad

1: nem képes következetes válaszokat adni vagy bizonytalan a dátumban

2: két napnál nem téved többet a dátumot illetően

3: két napnál többet téved a dátumot illetően

4: térben vagy a személyeket illetően dezorientált

7: az interjú során fel-alá járkál vagy nyugtalan

Teljes pontszám (maximum 67 pont):

A vizsgálatvezető monogramja:

A CIWA-Ar nem jogdíjas termék, szabadon reprodukálható. A megvonási tünetek monitorozása a mérőeszköz segítségével körülbelül 5 perc alatt elvégezhető. Az elérhető maximális pontszám 67 pont. A 10 pontnál kevesebbet elérő páciensek általában nem igényelnek további farmakoterápiát a megvonási tünetek miatt.

2. melléklet |Az Alkohol Megvonási Skála (AMS) használati útmutatója [9]

\section{Általános leírás}

Az Alkohol Megvonási Skála (AMS) az alkohol okozta megvonási szindróma (AMSZ) felmérésére, monitorozására alkalmas mérőeszköz (Sullivan et al., 1989). Az AMS tíz tételét külön-külön, az annak felvételét végző személy megfigyelései, illetve a páciens válaszai alapján kell pontozni. Maximálisan 67 pont adható. A skála felvétele hozzájárul az AMSZ felismeréséhez, annak monitorozásához, továbbá az optimális terápia megválasztásához.

\section{Instrukciók}

- A mérőeszköz alapján történjen a páciens vizsgálata.

- Magyarázza el a vizsgálat menetét és annak lehetséges kimeneteleit a páciensnek.

- Biztosítsunk lehetőséget arra, hogy a páciens feltehesse kérdéseit, és hagyjunk időt a válaszadásra.

- Amennyiben szükséges, törekedjen a biztonságos körülmények kialakítására, mielőtt megkezdi a vizsgálatot.

- Rögzítse a páciens vitális paramétereit. Ezen adatok nem kerülnek felhasználásra az összpontszámban, ugyanakkor fontos klinikai információt nyújtanak. A paraméterek enyhe eltérései gyakoriak lehetnek.

- Az AMS kérdéseit egymást követő sorrendben tegye fel, és pontozzon minden egyes tételt.

- A tételekre adott pontszámok összeadásával számolja ki az összpontszámot.

- Tájékoztassa a pácienst a vizsgálat eredményéról. Tájékoztassa a pácienst a kezelés további menetéről.

Az AMS felvételének megkezdése

1. Kezdje meg az AMS felvételét, ha a páciens anamnesztikus adatai arra utalnak, hogy van esély a megvonásos szindróma kialakulására.

2. ...ha a páciens anamnesztikus adatai korábbi megvonásos szindrómára utalnak.

3. ...ha a páciens a megelőző időszakban nagy mennyiségben fogyasztott alkoholt.

4. ...ha a páciens az elmúlt 12 órában alkoholt fogyasztott.

5. Amennyiben a kórtörténet nem egyértelmú, a páciens obszervációja szükséges, ameddig megvonási tünetek nem jelentkeznek.

\section{Az AMS felvételének befejezése}

Amennyiben az AMS-összpontszám < 10 három egymást követő vizsgálatkor, a méróeszköz ismételt felvétele nem szükséges (az idő tekintetében lehetnek egyéni eltérések). Ugyanakkor a páciens tüneteinek monitorozását, azok lehetséges exacerbatiója miatt folytassa.

\section{Fontos megjegyzések}

- Az ellátás első óráiban, illetve középsúlyos vagy súlyos megvonási szindróma esetén minden esetben ébressze fel a pácienst a vizsgálathoz. Ébredéskor súlyos megvonási tünetek észlelhetők.

- A méróeszköz felvételekor tartsa a szemkontaktust.

- Lassan és világosan beszéljen, ha szükséges, fogalmazza újra a kérdéseket.

- Ne konfrontálódjon a pácienssel. A pontozás szubjektív és objektív tünetekre, illetve a vizsgáló személy megfigyelésére épül.

- Amennyire lehet, törekedjen pozitív visszajelzésekre.

Az AMS használati útmutatója a Centre of Addiction and Mental Health (Centre de toxicomanie et de santé mentale) CIWA-Ar ajánlása alapján készült. 
Anyagi támogatás: A tanulmány elkészítését a Nemzeti Kutatási, Fejlesztési és Innovációs Hivatal (K111938, KKP126835), továbbá az Emberi Erőforrás Fejlesztési Operatív Program (EFOP-3.6.1-16-2016-00008) támogatta.

Szerzői munkamegosztás: L. B. A.: A kutatási téma felvetése, kidolgozása, a betegek bevonása, az adatbázis előkészítése, a közlemény megírása. P. I. K., K. Cs.: A szakirodalmi háttér megteremtése, a közlemény megírása. D. I.: A betegek bevonásának átfogó szervezése, monitorozása. K. J., J. Z.: A kutatási terv kidolgozása, a kézirat felépítése és megírása. Sz. J., K. G.: Az alkalmazott mérőeszköz látszatérvényességének tesztelése, általános leírásának, instrukciójának elkészítése. D. Zs.: A kutatási téma felvetése, kidolgozása, az alkalmazott mérőeszköz látszatérvényességének tesztelése, általános leírásának, instrukciójának elkészítése, a kézirat megírása. A. B.: A vizsgálat megvalósításának szervezése, a kutatási téma felvetése, kidolgozása, az adatbázis előkészítése, a statisztikai elemzések elvégzése, a közlemény megírása. A cikk végleges változatát valamennyi szerző elolvasta és jóváhagyta.

Érdekeltségek: A szerzőknek nincsenek a cikk témájával kapcsolatos érdekeltségeik.

\section{Köszönetnyilvánítás}

Ezúton szeretnénk megköszönni $d r$. Domján Nórának, dr. Dudás Évának, dr. Németh Viola Lucának, Kovács Ildikónak az AMS fordítását. Köszönettel tartozunk továbbá $d r$. Albert Anitának, dr. Pejin Andreának és dr. Kádár Bettinának a tesztfelvételben nyújtott segítségért.

\section{Irodalom}

[1] World Health Organization. Global status report on alcohol and health 2018. WHO, Geneva, 2018

[2] World Health Organization. World health statistics 2017: monitoring health for the SDGs, sustainable development goals. WHO, Geneva, 2017. Available from: http://www.who.int/ iris/handle/10665/255336. License: CC BY-NC-SA 3.0 IGO [accessed: March 26, 2019].

[3] American Psychiatric Association. Diagnostic and statistical manual of mental disorders (5th edn.). American Psychiatric Association, Arlington, VA, 2013.

[4] Környei E, Kassai-Farkas Á. A few of the neuropsychiatric consequences of alcohol disorder. [Az alkoholbetegségek néhány neuropszichiátriai következménye.] Addiktológia 2005; 4: 280-296 [Hungarian]

[5] Radics J. Difficulties in recognizing delirious disturbance of consciousness. [A delirozus tudatzavar felismerésének nehézségei.] Hippocrates 2011; 2: 59-60. [Hungarian]

[6] Pittman B, Gueorguieva R, Krupitsky E, et al. Multidimensionality of the Alcohol Withdrawal Symptom Checklist: a factor analysis of the Alcohol Withdrawal Symptom Checklist and CIWA-Ar. Alcohol Clin Exp Res. 2007; 31: 612-618.
[7] Holzman SB, Rastegar DA. AST: a simplified 3-item tool for managing alcohol withdrawal. J Addict Med. 2016; 10: 190195.

[8] Rastegar DA, Applewhite D, Alvanzo AA, et al. Development and implementation of an alcohol withdrawal protocol using a 5 -item scale, the Brief Alcohol Withdrawal Scale (BAWS). Subst Abus. 2017; 38: 394-400.

[9] Sullivan JT, Sykora K, Schneiderman J, et al. Assessment of alcohol withdrawal: the revised clinical institute withdrawal assessment for alcohol scale (CIWA-Ar). Br J Addict. 1989; 84: 13531357.

[10] Williams D, Lewis J, McBride A. A comparison of rating scales for the alcohol-withdrawal syndrome. Alcohol Alcohol. 2001; 36: 104-108.

[11] Foy A, McKay S, Ling S, et al. Clinical use of a shortened alcohol withdrawal scale in a general hospital. Intern Med J. 2006; 36: 150-154.

[12] Fuller RK, Gordis E. Refining the treatment of alcohol withdrawal. JAMA 1994; 272: 557-558.

[13] Bakhla AK, Khess CR, Verma V, et al. Factor structure of CIWA-Ar in alcohol withdrawal. J Addict. 2014; 2014: 745839.

[14] Stuppaeck CH, Barnas C, Falk M, et al. Assessment of the alcohol withdrawal syndrome - validity and reliability of the translated and modified Clinical Institute Withdrawal Assessment for Alcohol scale (CIWA-A). Addiction 1994; 89: 1287-1292.

[15] Zhuo C, Huang Y, Tang Y, et al. Validity and reliability of Chinese version of alcohol withdrawal scale (AWS). Chin J Behav Med Brain Sci. 2010; 19: 661-663.

[16] Bonnet U, Hamzavi-Abedi R, Specka M, et al. An open trial of gabapentin in acute alcohol withdrawal using an oral loading protocol. Alcohol Alcohol. 2009; 45: 143-145.

[17] Girish K, Vikram Reddy K, Pandit LV, et al. A randomized, open-label, standard controlled, parallel group study of efficacy and safety of baclofen, and chlordiazepoxide in uncomplicated alcohol withdrawal syndrome. Biomed J. 2016; 39: 72-80.

[18] Gual A, Lehert P. Acamprosate during and after acute alcohol withdrawal: a double-blind placebo-controlled study in Spain. Alcohol Alcohol. 2001; 36: 413-418.

[19] Favre JD, Allain H, Aubin HJ, et al. Double-blind study of cyamemazine and diazepam in the alcohol withdrawal syndrome. Hum Psychopharmacol. 2005; 20: 511-519.

[20] Förg A, Hein J, Volkmar K, et al. Efficacy and safety of pregabalin in the treatment of alcohol withdrawal syndrome: a randomized placebo-controlled trial. Alcohol Alcohol. 2012; 47: $149-155$.

[21] Hendey GW, Dery RA, Barnes RL, et al. A prospective, randomized trial of phenobarbital persus benzodiazepines for acute alcohol withdrawal. Am J Emerg Med. 2011; 29: 382-385.

[22] Seifert J, Peters E, Jahn K, et al. Treatment of alcohol withdrawal: chlormethiazole vs. carbamazepine and the effect on memory performance - a pilot study. Addict Biol. 2004; 9: 43-51.

[23] Rózsa S, Nagybányai Nagy O, Oláh A. (eds.) The basics of psychological measurment. [A pszichológiai mérés alapjai.] Bölcsész Konzorcium Kiadó, Budapest, 2006; p. 173. [Hungarian]

[24] Babor TF, de la Fuente JR, Saunders J, et al. The Alcohol Use Disorders Identification Test: guidelines for use in primary care (WHO Publication No. 92.4). World Health Organization, Geneva, 1992.

[25] Guy W. Clinical Global Impression. ECDEU Assessment Manual for Psychopharmacology, revised. National Institute of Mental Health, Rockville, MD, 1976. 
[26] Kattimani S, Bharadwaj B. Clinical management of alcohol withdrawal: a systematic review. Ind Psychiatry J. 2013; 22: 100108.

[27] Reoux JP, Oreskovich MR. A comparison of two versions of the Clinical Institute Withdrawal Assessment for Alcohol: the CIWA-Ar and CIWA-AD. Am J Addict. 2006; 15: 85-93.

[28] Pendharkar S, Mattoo SK, Grover S. Sexual dysfunctions in alcohol-dependent men: a study from north India. Indian J Med Res. 2016; 144: 393-399.

[29] Kraemer KL, Mayo-Smith MF, Calkins DR. Independent clinical correlates of severe alcohol withdrawal. Subst Abus. 2003; 24: 197-209.
[30] Jose M, Mathaiyan J, Kattimani S, et al. Role of CYP2C19 gene polymorphism in acute alcohol withdrawal treatment with loading dose of diazepam in a South Indian population. Eur J Clin Pharmacol. 2016; 72: 807-812.

(Lázár Bence András dr., Szeged, Kálvária sgt. 57., 6725 e-mail: lazar.bence.andrás@med.u-szeged.hu)

és

Andó Bálint dr., Szeged, Kálvária sgt. 57., 6725 e-mail: ando.balint@med.u-szeged.hu)

\section{A rendezvények és kongresszusok híranyagának leadása}

a lap megjelenése előtt legalább 40 nappal lehetséges, a 6 hetes nyomdai átfutás miatt.

Kérjük megrendelőink szíves megértését.

A híranyagokat a következő címre kérjük:

Orvosi Hetilap titkársága: edit.budai@akademiai.hu

Akadémiai Kiadó Zrt.

A cikk a Creative Commons Attribution 4.0 International License (https://creativecommons.org/licenses/by/4.0/) feltételei szerint publikált Open Access közlemény, melynek szellemében a cikk bármilyen médiumban szabadon felhasználható, megosztható és újraközölhető, feltéve, hogy az eredeti szerző és a közlés helye, illetve a CC License linkje és az esetlegesen végrehajtott módosítások feltüntetésre kerülnek. (SID_1) 